\title{
Epidemic Characteristics of Foot and Mouth Disease on the Buffaloes and Cows in Lang Son Province, Vietnam
}

\author{
Dang Xuan Binh ${ }^{1,}$, Dam Thi Phuong Mai \\ ${ }^{1}$ Faculty of Animal Husbandry and Veterinary Medicine, Thai Nguyen University of Agriculture and Forestry, Vietnam \\ ${ }^{2}$ Sub Department of Animal Health, Lang Son Province, Vietnam
}

Email address:

binhdx@tnu.edu.vn (D. X. Binh)

${ }^{*}$ Corresponding author

\section{To cite this article:}

Dang Xuan Binh, Dam Thi Phuong Mai. Epidemic Characteristics of Foot and Mouth Disease on the Buffaloes and Cows in Lang Son Province, Vietnam. Animal and Veterinary Sciences. Vol. 4, No. 4, 2016, pp. 62-71. doi: 10.11648/j.avs.20160404.13

Received: July 14, 2016; Accepted: August 23, 2016; Published: August 25, 2016

\begin{abstract}
From 2011 to 2015, in Lang Son province, Vietnam, foot and mouth disease (FMD) occurred in 11 districts and town. The virus causing FMD on the cattle in Lang Son belonged to type O and type A. While type Asia 1 virus had occurred in some other provinces in Vietnam, it was not found in Lang Son. FMD epidemic in Lang Son province had no regularity. In one district, the epidemic occurred continuously in two or three years (e.g. in Binh Gia and Van Quan districts) while in some others, it occurred only once (e.g. Cao Loc district and Lang Son city). On average, 1.26\% of the buffaloes and cows were infected with FMD per year. Precisely, $1.39 \%$ of the buffaloes and $0.75 \%$ of the cows were infected. FMD on the buffaloes and cows in Lang Son was under the influence of (i) the weather and climate conditions (especially the years with extremely cold winter), (ii) the seasonal agricultural practice in the locality (during the time of the year when the cattle were used for ploughing and pulling carts for the crops, their health was relatively declined), and (iii) the results of vaccination in early Autumn - Winter season (the smaller the number of cattle vaccinated, the higher the number of cattle infected). These influences were clearly observed in 2011 with the highest number of cattle infected $(8,929$ infected cattle, accounting for 5.3\% of the herds, whereas the average rate of infection in the whole five studied years was $1.26 \%$ ). The sources of FMD were identified as mainly came from the infected cattle which had been medically treated and clear of the symptoms, yet still carried and shed the virus to the environment. On average, the rate of natural virus infection on the cattle in Lang Son was $33.23 \%$. Of which, the rate was highest in the following districts: Bac Son (66.66\%), Van Quan (50\%), Trang Dinh (32.88\%) and Binh Gia (28.57\%). After being injected with FMD vaccine (Aftovax Bivalent, with 2 types of O and A), 100\% of the cattle had immune response. 30 days after vaccination, the rate of protection varied from $86.6 \%$ to $100 \%$. Six months after the first vaccination shot, a second one must be done for the vaccination to be effective.
\end{abstract}

Keywords: FMD, Type A, Type O, Disease, Buffaloes, Cows

\section{Introduction}

Foot and mouth disease is an acute communicable disease which spreads quickly and causes serious damages to the cattle such as the buffaloes and cows and pigs. It is listed in list $\mathrm{A}$ of the dangerous communicable diseases by Office International Epizooties (OIE) [1, 2, 11, and 17].

There are seven types of FMD virus: A, O, C, Asia1, SAT1, SAT2, and SAT3. In South East Asia, the most common ones are types $\mathrm{O}, \mathrm{A}$, and Asia1. In Vietnam, the ones which have caused diseases on the buffaloes and cows and pigs are types
O, A and Asia1 [3, 4, 6, 18, 19, 20 and 21].

Lang Son is a border mountainous province in the Northeast of Vietnam, with national roads running through the province, and the north of the province borders Chongzuo (Quangxi, China), with a border line of 253 kilometres, two international bordergates, two national bordergates, seven border markets, and local markets, which make the province an important center for exchanging and trading between Vietnam and China, to Central Asian and European countries.

During the five years, from 2011 to 2015, there were 187 FMD outbreaks in Lang Son. On average, 3.4 outbreaks occurred in each district or town per year. The number of 
outbreaks which becomes epidemics varied among the districts. During the five years, there were seven districts with 20 outbreaks or more, including Trang Dinh (21 outbreaks), Van Lang (26 outbreaks), Chi Lang (23 outbreaks), Huu Lung (27 outbreaks), Bac Son (23 outbreaks), Binh Gia (24 outbreaks) and Van Quan (29 outbreaks); there were only four districts with less than 10 outbreaks, including Cao Loc (2 outbreaks), Loc Binh (2 outbreaks), Dinh Lap (4 outbreaks) and Lang Son City (6 outbreaks).

The complex situation of FMD epidemic in Lang Son province and in the whole country in the past few years requires studies on the distribution and occurrence of FMD virus, to serve as a scientific ground for selection of suitable vaccines. This would contribute to improve the effectiveness of epidemic prevention and fighting, to ensure that the cattles are safe. These are the reasons why the study entitled "Epidemic Characteristics of Foot and Mouth Disease on the Buffaloes and Cows in Lang Son Province, Vietnam", was carried out from 2011 to 2015.

\section{Materials and Methods}

\subsection{Contents}

- Survey on epidemic situation of FMD on the buffaloes and cows in Lang Son province from 2011 to 2015.

- Serological assesment of the positive rate with the strains of FMD virus which have been found in Vietnam (O, A, Asia 1) on the buffaloes and cows in Lang Son.

- Identification of the type of virus which cause FMD on the buffaloes and cows in Lang Son province

\subsection{Animal Testing}

- Buffaloes and cows of different age groups

\subsection{Samples}

- Samples were the epithelium tissues and vesicles on the infected buffaloes and cows collected from outbreaks in Lang Son province.

- Blood samples of healthy buffaloes and cows in Lang Son for examining the presence of FMD virus.

- FMD virus.

- Antisera to FMD virus collected from buffaloes and cows blood samples in Lang Son province.

- Other necessary equipments, materials, and environment chemicals.

\subsection{Time Duration}

- Data from epidemic survey from 2011 to 2015

- Study the presence of FMD virus on the buffaloes and cows in the two years of 2014 and 2015.

\subsection{Study Area}

- The samples were collected by the Animal Health Department of Lang Son province.
- The tests and examinations of the samples were conducted at the National Centre for Veterinary Diagnosis and the Regional Animal Health Office No. II.

- The epidemic characteristics of FMD were studied on the buffaloes and cows in Lang Son province from 2011 to 2015

- Serological assessment of positive rate with the main virus strains (O, A, Asia 1), and assessment of the virus infection rate on the buffaloes and cows were conducted at the laboratories of the National Centre for Veterinary Diagnosis and the Regional Animal Health Office No. II.

- Identification of the types of virus which cause FMD on the buffaloes and cows were done in Lang Son province

\subsection{Methodology}

\subsubsection{ELISA}

ELISA technique was used to identify the antigen and examine the serotypes of FMD virus. This is a quick dianogsis method, with high specifity and sensitivity. The tests based on the principles of serology to FMD virus included two types: (i) tests in which antibodies to structural proteins (SPs) of virus were identified, and (ii) tests in which antibodies to nonstructural proteins (NSTs) of virus were identified.

The blood type specific SP tests identifying the antibodies were developed by vaccination and infection.

\subsubsection{ABC - ELISA}

ELISA methodology allows for identification of antibodies (types and density of antibodies), and of the types of FMD virus causing the disease. However, it is not possible to use ELISA technique to determine whether the existence of the antibodies relates to natural infection or it is due to vaccination. In order to clear the confusion, 3ABC-ELISA method was used to determine the types of antibodies against non-structural proteins $3 \mathrm{ABC}$ antigen of FMD virus.

In fact, only cattles which are natural infected with FMD virus are possitve with $3 \mathrm{ABC}$-ELISA reactions.

\subsubsection{Dianogsis with Real-Time RT-PCR Technique}

According to $[17,19,20]$, primers FM1F-FM1R can be used to multiply the non-coding gene area 5'UTR from RNA templates of the strains $\mathrm{O}, \mathrm{A}, \mathrm{C}$, and Asia 1, and the product was cDNA with the lengths of 323- 328 nucleotide, and the lengths vary according to the types.

Primer sequence 1 (FM1F): 5'-GCCTG-GTCTT-TCCAGGTCT-3' (positive strand)

Primer sequence 2 (FM1R): 5'-CCAGT-CCCCT-TCTCAGATC-3' (negative strand)

Cycle parameter: $94^{\circ} \mathrm{C}$ in five minutes $(1$ cycle $) ; 94^{\circ} \mathrm{C}$ in one minute, $55^{\circ} \mathrm{C}$ in one minute, $72^{\circ} \mathrm{C}$ in two minutes $(30$ cycles); $72^{\circ} \mathrm{C}$ in seven minutse ( 1 cycle).

Designed primers which can magnify the encoding gene sequences 1D (VP1) of FMD virus related to the strains of $\mathrm{O}$, A, C, and Asia. The sense primer of the virus was designed 
to have the same sequences as the $1 \mathrm{C}$ (VP3) of the virus. The antisense primer NK61 was designed based on the gene sequence $2 \mathrm{~B}$ of the strains $\mathrm{O}, \mathrm{A}, \mathrm{C}$, and SAT2. The sequence of primer NK72 used for identifying FMD virus was used in all the tests on RNA sequence [5, 9, 13, and 15].

Table 1. Primers used for identification of the prevalence of FMD virus type $O, A$ and Asial.

\begin{tabular}{lll}
\hline Primer & Nucleotide sequence (5'-3') & Size (bp) \\
\hline Positive sense & & \\
O-1C124 (ARS4) & ACCAACCTCCTTGATGTGGCT & 1301 \\
O-1C564 & AATTACACATGGCAAGGCCGACGTG & 861 \\
O-1C609 (Ovp3) & TAGTGCTGGTAAAGACTTTGAGCT & 816 \\
A-1C562 & TACCAAATTACACACGGGAA & $863-866$ \\
A-1C612 & TAGCGCCGGCAAAGACTTTGA & $813-816$ \\
As1-1C505 & TACACTGCTTCTGACGTGGC & $908-914$ \\
As1-1C616 & GGCAAGGACTTTGAGTTTCGC & $797-803$ \\
Negative sense & & \\
FMD-2B58 (NK61) & \\
FMD-2A34 (NK72) & GACATGTCCTCCTGCATCTG & \\
\hline
\end{tabular}

\subsubsection{Blood Sample Collection}

- $3 \mathrm{ml}$ of blood was sucked from the neck vein of each buffaloes and cows by syringes

- Blood serum was separated, stored in Eppendorf tubes at the temperature from $2-4^{\circ} \mathrm{C}$, and sent to the laboratory.

- The blood serum was stored at $4^{\circ} \mathrm{C}$ if examined within one week or at $-30^{\circ} \mathrm{C}$ if examined later.

\subsubsection{Epithelium Tissue Sample Collection}

- Clincal examination and selection of the cattles with FMD at early stage. The samples were collected from the new wounds, and not from the ones which had formed scars or had been sterised and treated.

- Epithelium tissue samples were collected from the cattles which showed symptoms of FMD according to the guidelines of the Agency of Animal Health of Vietnam and the principles of biosafety of OIE for examining and identifying the types of virus.

- Epithelium tissue samples include those from the tongue, gum, hoof gaps, the peeling skin surrounding the hooves formed when the vesicles broke, and the fluid substances in the vesicles.

- The samples were stored at $4-8^{\circ} \mathrm{C}$ in the mixture of PBS $0.04 \mathrm{M}$ and Glycerin (Rate 1: 1) $\mathrm{pH}=7.2-7.6$ during transportation to the laboratory.

- The samples which were not examined immediately were stored at $-80^{\circ} \mathrm{C}$ for later laboratory performances.

\section{Results and Discussion}

\subsection{Epidermic Characteristics of the FMD on Buffaloes and Cows in Lang Son Province}

In order to evaluate the occurrence of FMD in Lang Son province in recent years, a retrospective study was carried out, in which, data on the FMD outbreaks on buffaloes and cows in Lang Son province in five consecutive years from 2011 to 2015 was collected. The results are presented in table 2 .
Table 2. FMD on buffaloes and cows in Lang Son province.

\begin{tabular}{llllllll}
\hline \multirow{2}{*}{ TT } & $\begin{array}{l}\text { FMD areas } \\
\text { (districts) }\end{array}$ & \multicolumn{7}{l}{ Number of outbreaks } & Total \\
\cline { 2 - 7 } & $\mathbf{2 0 1 1}$ & $\mathbf{2 0 1 2}$ & $\mathbf{2 0 1 3}$ & $\mathbf{2 0 1 4}$ & $\mathbf{2 0 1 5}$ & \\
\hline 1 & Trang Dinh & 20 & & 1 & & & 21 \\
2 & Van Lang & 20 & 5 & & 1 & 26 \\
3 & Cao Loc & 2 & & & & 2 \\
4 & Loc Binh & 1 & & & 1 & & 2 \\
5 & Dinh Lap & 2 & & & 2 & & 4 \\
6 & Lang Son City & 4 & 2 & & & & 6 \\
7 & Chi Lang & 19 & 1 & 1 & 2 & & 23 \\
8 & Huu Lung & 26 & 1 & & & & 27 \\
9 & Bac Son & 17 & & 5 & & 1 & 23 \\
10 & Binh Gia & 19 & 3 & 2 & & & 24 \\
11 & Van Quan & 22 & 3 & 3 & & 1 & 29 \\
Total & & 152 & 15 & 12 & 6 & 2 & 187 \\
\hline
\end{tabular}

Table 2 shows that in the five years from 2011 to 2015, in Lang Son province, there were 187 FMD outbreaks. On average, there were 3.4 outbreaks/year in each district/town ( 187 outbreaks/11 districts/five years $=3.4)$.

The number of FMD outbreaks depended on the locality. In the five years, there were seven districts with 20 outbreaks or more, including Trang Dinh (21 outbreaks), Van Lang (26 outbreaks), Chi Lang (23 outbreaks), Huu Lung (27 outbreaks), Bac Son (23 outbreaks), Binh Gia (24 outbreaks) and Van Quan (29 outbreaks); four districts with less than ten 10 outbreaks, including Cao Loc (2 outbreaks), Loc Binh (2 outbreaks), Dinh Lap (4 outbreaks) and Lang Son City (6 outbreaks). FMD occurred in Lang Son in all the five years. The number of FMD outbreaks among the years varied. On average, there were 37.4 outbreaks/year, with the highest rate of 152 outbreaks in 2011. The FMD in Lang Son occurred irregularly. In one district, there were outbeaks every year in two or three consecutive years (e.g. Binh Gia and Van Quan districts), while in some others the outbreaks occurred and did not happen again several years after that (Cao Loc, Lang Son City). This finding was similar to that of $[9,10]$.

\subsubsection{Statistics of the Buffaloes and Cows Infected with FMD}

Statistics on the buffaloes and cows infected with FMD in 
Lang Son province in five years from 2011 to 2015 were collected. The results are presented in tables $3 \mathrm{a}$ and $3 \mathrm{~b}$.

Table 3a. Buffaloes and cows infected with FMD.

\begin{tabular}{lllllll}
\hline \multirow{2}{*}{ Year } & Buffaloes & & \multicolumn{3}{l}{ Cows } \\
\cline { 2 - 7 } & Total number & Infected & Rate (\%) & Total number & Infected & Rate (\%) \\
\hline 2011 & 133,850 & 8,253 & 6.16 & 34,414 & 676 & 1.96 \\
2012 & 128,531 & 63 & 0.05 & 31,168 & 3 & 0.009 \\
2013 & 121,375 & 349 & 0.28 & 31,006 & 266 & 0.86 \\
2014 & 121,309 & 73 & 0.06 & 32,109 & 242 & 0.75 \\
2015 & 122,060 & 31 & 0.02 & 32,783 & 35 & 0.11 \\
Total & 627,125 & 8,769 & 1.39 & 161,480 & 1,222 & 0.75 \\
\hline
\end{tabular}

Table 3b. Buffaloes and cows with FMD.

\begin{tabular}{llll}
\hline Year & Total number of buffaloes and cows & Infected & Rate (\%) \\
\hline 2011 & 168,264 & 8,929 & 5.30 \\
2012 & 159,699 & 66 & 0.04 \\
2013 & 152,381 & 615 & 0.40 \\
2014 & 153,418 & 315 & 0.20 \\
2015 & 154,843 & 66 & 0.04 \\
Total & 788,605 & 9,991 & 1.26 \\
\hline
\end{tabular}

Tables $3 \mathrm{a}$ and $3 \mathrm{~b}$ show that the buffaloes and cows with FMD account for an average of $1.26 \%$ /year; with $1.39 \%$ /year for buffaloes and $0.75 \% /$ year for cows. The disease occurred every year from 2011 to 2015 . The number of buffaloes and cows infected varied among the months due to the influence of the weather and vaccination. For example in 2011 when it was extremely cold in the winter, the Rate of buffaloes and cows with FMD was highest with 8.929 infected (or 5.3\%, compared to the five year's average of $1.26 \%$ ). This finding was similar to that of $[9,10$, and 14].

With the above results, epidemically speaking, it could be confirmed that the source of the disease still existed. The main source was the buffaloes and cows with FMD which had been treated with the disease and shown no symptom, yet still carried the viruses and release them to the surrounding environment. The new buffaloes and cows which had no immunity or no longer been protected would be sensititve to the viruses and infected with the disease. This result was similar to that of $[10,15,20$, and 21].

\subsubsection{FMD on the Buffaloes and Cows in Lang Son Province with by Seasons}

In order to determine the influence of climatic and weather conditions to the outbreaks of FMD, statistics on cases of FMD on buffaloes and cows (Totally and separately) occurring in each of the the four seasons in Lang Son province in five years from 2011 to 2015 . The results are presented in tables $4 \mathrm{a}, 4 \mathrm{~b}$, and $4 \mathrm{c}$.

Table 4a. FMD on the buffaloes and cows in Lang Son province by seasons (in the five years from 2011 to 2015).

\begin{tabular}{llllll}
\hline \multirow{2}{*}{ Areas } & \multicolumn{5}{l}{ Number of buffaloes and cows with FMD by seasons } \\
\cline { 2 - 6 } & Spring & Summer & Autumn & Winter & Total \\
\hline Trang Dinh & 368 & 0 & 23 & 514 & 905 \\
Van Lang & 526 & 77 & 121 & 651 & 1,375 \\
Cao Loc & 0 & 0 & 0 & 56 & 56 \\
Loc Binh & 0 & 0 & 0 & 175 & 175 \\
Dinh Lap & 15 & 0 & 0 & 56 & 71 \\
Lang Son City & 347 & 0 & 0 & 446 & 793 \\
Chi Lang & 825 & 30 & 181 & 1,763 & 2,799 \\
Huu Lung & 479 & 0 & 65 & 682 & 1,226 \\
Bac Son & 282 & 13 & 20 & 14 & 329 \\
Binh Gia & 298 & 27 & 0 & 445 & 770 \\
Van Quan & 631 & 0 & 0 & 861 & 1,492 \\
Total & 3,771 & 147 & 410 & 5,663 & 9,991 \\
\hline
\end{tabular}

Table 4a shows that from 2011 to 2015 , the number of buffaloes and cows with FMD was 3,771 in Spring; in Summer; 410 in Autumn; and 5,663 in Winter. The total number of buffaloes and cows infected with the disease in Lang Son was 9,991 in the five years.

Table 4a shows that FMD in Lang Son was critical. Besides, it is very difficult to control the sources of the disease. It is because once infected with the disease and being treated, although there might be no sign of the symptom, the cattle still carry and realease FMD viruses to the environment for a long time after that (one or two years), which causes great challenges to the prevention of the disease's outbreaks.

Table 4b. FMD on Buffaloes by seasons.

\begin{tabular}{|c|c|c|c|c|c|c|c|c|c|c|}
\hline \multirow{3}{*}{ Year } & \multirow{3}{*}{$\begin{array}{l}\text { Total number } \\
\text { of Buffaloes }\end{array}$} & \multirow{3}{*}{ Infected } & \multicolumn{8}{|l|}{ Seasons } \\
\hline & & & \multicolumn{2}{|l|}{ Spring } & \multicolumn{2}{|l|}{ Summer } & \multicolumn{2}{|l|}{ Autumn } & \multicolumn{2}{|l|}{ Winter } \\
\hline & & & Infected & Rate (\%) & Infected & Rate (\%) & Infected & Rate (\%) & Infected & Rate $(\%)$ \\
\hline 2011 & 133,850 & 8,253 & 3,402 & 41.22 & 98 & 1.19 & 341 & 4.13 & 4,412 & 53.46 \\
\hline 2012 & 128,531 & 63 & 63 & 100 & 0 & 0 & 0 & 0 & 0 & 0 \\
\hline 2013 & 121,375 & 349 & 0 & 0 & 40 & 11.46 & 23 & 6.59 & 286 & 81.95 \\
\hline 2015 & 122,060 & 31 & 0 & 0 & 0 & 0 & 6 & 19.35 & 25 & 80.65 \\
\hline Total & 627,125 & 8,769 & 3,465 & 39.41 & 138 & 1.57 & 370 & 4.22 & 4,796 & 54.70 \\
\hline
\end{tabular}


Table $4 \mathrm{~b}$ shows the situation of FMD on Buffaloes by seasons in 11 districts and towns in Lang Son from 2011 to 2015. Out of the 627,125 buffaloes, 8,769 were found with FMD. Of which, the number of buffaloes infected with the disease was 3,456 in Spring, accounting for 39.41\%; 138 in Summber, accounting for $1.57 \% ; 370$ in Autumn, accounting for $4.22 \%$; and 4,796 in winter, accounting for $54.70 \%$.

The results correspond with those in Table $4 \mathrm{a}$. It can be easily seen that there were most cases in winter (accounting for $54.80 \%$ of the total buffaloes infected with the disease); and the number of cases was lowest in Summer (accounting for $1.57 \%$ ). Thus, it can be seen that the climatic and weather conditions affect seasonal agriculture and husbandry practices in Lang Son and other provinces of similar conditions in Northern mountainous areas in Vietnam. This finding was similar to that of $[11,13]$.

Table 4 c. FMD on cows by seasons.

\begin{tabular}{|c|c|c|c|c|c|c|c|c|c|c|}
\hline \multirow{3}{*}{ Year } & \multirow{3}{*}{$\begin{array}{l}\text { Total number } \\
\text { of cows }\end{array}$} & \multirow{3}{*}{ Infected } & \multicolumn{8}{|c|}{ By seasons trong Year } \\
\hline & & & \multicolumn{2}{|l|}{ Spring } & \multicolumn{2}{|l|}{ Summer } & \multicolumn{2}{|l|}{ Autumn } & \multicolumn{2}{|l|}{ Winter } \\
\hline & & & Infected & Rate (\%) & Infected & Rate (\%) & Infected & Rate (\%) & Infected & Rate (\%) \\
\hline 2011 & 34,414 & 676 & 321 & 47.48 & 冫 & 1.33 & 26 & 3.85 & 320 & 47.33 \\
\hline 2012 & 31,168 & 3 & 3 & 100 & 0 & 0 & 0 & 0 & 0 & 0 \\
\hline 2013 & 31,006 & 266 & 0 & 0 & 0 & 0 & 0 & 0 & 266 & 0 \\
\hline 2014 & 32,109 & 242 & 24 & 9.92 & 0 & 0 & 0 & 0 & 218 & 90.08 \\
\hline 2015 & 32,783 & 35 & 0 & 0 & 0 & 0 & 14 & 40 & 21 & 60 \\
\hline Total & 161,480 & 1,222 & 306 & 25.04 & 9 & 0.74 & 40 & 3.27 & 867 & 70.95 \\
\hline
\end{tabular}

Table 4c shows FMD on cows in 11 districts and towns in Lang Son by seasons. O、ut of the total 161,480 cows, 1,222 were found with FMD. The number of cows with FMD was 306 in Spring, accounting for 25.04\%; 9 in Summer, accounting for $0.74 \%$; 40 in Autumn, accounting for $3.27 \%$; and 867 in Winter, accounting for $70.95 \%$. The results show that the situation of FMD on cows was relatively different from that on buffaloes. The number of cows with FMD was lower that that of buffaloes in Spring, Summer, and Autumn, but higher in Winter $(70.95 \%$ and $54.70 \%)$.

\subsubsection{FMD on Buffaloes and Cows by Age}

In fact, besides being species dependent, the sensitivity of the buffaloes and cows towards FMD also depends on age and other factors relating to active and passive immunity. In order to determine the relationship between age factor and FMD, a retrospective study of the statistics of the buffaloes and cows with FMD by age from 2011 to 2015 was carried out. The cattle were divided into three age groups: (i) less than two years of age, (ii) from two to five years of age, and (iii) over five years of age. The results are presented in tables $5 \mathrm{a}, 5 \mathrm{~b}$ and $5 \mathrm{c}$.

Table 5a. Buffaloes with FMD by age.

\begin{tabular}{|c|c|c|c|c|c|c|c|}
\hline \multirow{3}{*}{ Year } & \multirow{3}{*}{ No. of Buffaloes with FMD } & \multicolumn{6}{|c|}{ Age of Buffaloes (Year) } \\
\hline & & \multicolumn{2}{|l|}{$<2$} & \multicolumn{2}{|l|}{$2-5$} & \multicolumn{2}{|l|}{$>5$} \\
\hline & & No. infected & $\%$ & No. infected & $\%$ & No. infected & $\%$ \\
\hline 2011 & 8,253 & 453 & 5.49 & 851 & 10.31 & 6,949 & 84.21 \\
\hline 2012 & 63 & 7 & 11.11 & 14 & 22.22 & 42 & 66.67 \\
\hline 2013 & 349 & 29 & 8.31 & 53 & 15.18 & 267 & 76.50 \\
\hline 2014 & 73 & 6 & 8.22 & 11 & 15.06 & 56 & 76.71 \\
\hline 2015 & 31 & 3 & 9.68 & 4 & 12.90 & 24 & 77.42 \\
\hline
\end{tabular}

Table 5b. Cows with FMD by age.

\begin{tabular}{|c|c|c|c|c|c|c|c|}
\hline \multirow{3}{*}{ Year } & \multirow{3}{*}{ Total Cows with FMD } & \multicolumn{6}{|l|}{ Age of cows } \\
\hline & & \multicolumn{2}{|l|}{$<2$} & \multicolumn{2}{|l|}{$2-5$} & \multicolumn{2}{|l|}{$>5$} \\
\hline & & No. infected & $\%$ & No. infected & $\%$ & No. infected & $\%$ \\
\hline 2011 & 676 & 26 & 3.84 & 67 & 9.91 & 583 & 86.25 \\
\hline 2012 & 3 & 0 & 0 & 1 & 33.33 & 2 & 66.67 \\
\hline 2013 & 266 & 11 & 4.13 & 46 & 17.29 & 209 & 78.57 \\
\hline 2014 & 242 & 15 & 6.20 & 58 & 23.69 & 169 & 69.84 \\
\hline 2015 & 35 & 2 & 5.71 & 12 & 34.29 & 21 & 60 \\
\hline
\end{tabular}


Table 5c. Buffaloes and Cows with FMD by age.

\begin{tabular}{|c|c|c|c|c|c|c|c|}
\hline \multirow{3}{*}{ Year } & \multirow{3}{*}{$\begin{array}{l}\text { Total No. of buffaloes and } \\
\text { cows with FMD }\end{array}$} & \multicolumn{6}{|c|}{ Age of buffaloes and cows (Year) } \\
\hline & & \multicolumn{2}{|l|}{$<2$} & \multicolumn{2}{|l|}{$2-5$} & \multicolumn{2}{|l|}{$>5$} \\
\hline & & No. infected & $\%$ & No. infected & $\%$ & No. infected & $\%$ \\
\hline 2011 & 8,929 & 479 & 5.36 & 918 & 10.28 & 7,532 & 84.35 \\
\hline 2012 & 66 & 7 & 10.60 & 15 & 22.72 & 44 & 66.67 \\
\hline 2013 & 615 & 40 & 6.50 & 99 & 16.09 & 476 & 77.39 \\
\hline 2014 & 315 & 21 & 6.67 & 69 & 21.90 & 225 & 71.42 \\
\hline 2015 & 66 & 5 & 7.57 & 16 & 24.24 & 45 & 68.18 \\
\hline
\end{tabular}

Tables 5a, 5b and 5c show that FMD occurs on buffaloes and cows of all the age groups; (i) less than two years of age, (ii) from two to five years of age, and (iii) over five years of age. Of which, the highest rates of FMD infection occurred on Buffaloes and cows over five years of age, with $66.67 \%$ to $84.21 \%$ of the buffaloes, $60 \%$ to $86.25 \%$ of the cows; and $68.18 \%$ to $84.35 \%$ of the total buffaloes và cows with FMD. This result corresponds to previous reports on FMD on buffaloes and cows in Bac Kan, Cao Bang, and several other Northern mountainous provinces in Vietnam.

\subsubsection{Buffaloes and Cows Died of FMD}

The number of buffaloes and cows died of FMD in 11 districts and towns in Lang Son province from 2011 to 2015 was studied using veterinary epidemiology criteria. The results are presented in Table 6.

Table 6. Buffaloes and cows died of FMD.

\begin{tabular}{lccl}
\hline $\begin{array}{l}\text { Epidemiological } \\
\text { Criteria }\end{array}$ & No. infected & Dead toll & Rate (\%) \\
\hline \multicolumn{2}{l}{ The buffaloes and cows died of FMD by age } & \\
$<2$ & 552 & 34 & 6.15 \\
$2-5$ & 1,117 & 87 & 7.78 \\
$>5$ & 8,322 & 168 & 2.02 \\
The buffaloes and cows died of FMD by seasons & \\
Spring & 3,771 & 109 & 2.89 \\
Summer & 147 & 2 & 1.36 \\
Autumn & 410 & 14 & 3.41 \\
Winter & 5,663 & 184 & 3.25 \\
The buffaloes and cows died of FMD by year & \\
2011 & 8,929 & 285 & 3.19 \\
2012 & 66 & 0 & 0 \\
2013 & 615 & 9 & 1.46 \\
2014 & 315 & 14 & 4.44 \\
2015 & 66 & 1 & 1.51 \\
\hline
\end{tabular}

\subsubsection{Number of Buffaloes and Cows Naturally Infected} with FMD Viruses (Those Without FMD Vaccination)

Blood samples from healthy buffaloes and cows (those with no clinical symptoms or clinical signs of FMD) were collected to assess natural FMD viruses infection (The buffaloes and cows had not been injected with FMD vaccines). The results are presented in Table 7.

Table 7. Buffaloes and cows which are positive with $3 A B C$ antigen of FMD viruses in the nature.

\begin{tabular}{lllll}
\hline NO. & Areas & $\begin{array}{l}\text { No. of samples } \\
\text { examined }\end{array}$ & $\begin{array}{l}\text { No. of positive } \\
\text { samples }\end{array}$ & Rate (\%) \\
\hline 1 & Trang Dinh & 298 & 98 & 32.88 \\
2 & Binh Gia & 7 & 2 & 28.57 \\
3 & Bac Son & 3 & 2 & 66.66 \\
4 & Van Quan & 2 & 1 & 50 \\
Total & & 310 & 103 & 33.23 \\
\hline
\end{tabular}

Table 7 shows that the blood samples of the buffaloes and cows in the four districts of Trang Dinh, Binh Gia, Bac Son and Van Quan found positive with $3 \mathrm{ABC}$ antigen of FMD viruses accounted for an average of $33.23 \%$. The rate was highest in Bac Son (66.66\%), Van Quan (50\%), Trang Dinh (32.88\%) and Binh Gia (28.57\%).

The result shows the relatively high rate of buffaloes and cows carrying FMD virus (accounting for 33.23\%), which means for every three cattles, there is one carrying FMD viruses. This is a source of the disease. The buffaloes and cows or other sensitive cattles such as pigs and goats which have not been immuned against FMD could easily catch the disease. The result also shows that there is a relation between the number of buffaloes and cows carrying the virus and the number of buffaloes and cows suffered from FMD from 2011 to 2015 . This result was similar to that of $[7,9]$.

\subsubsection{Buffaloes and Cows Infected with FMD Virus in Natural Conditions After Being Injected with FMD Vaccine}

Blood samples from healthy buffaloes and cows which showed no symptom or clinical signs of FMD to assess the natural infection of FMD in natural conditions after being injected with FMD vaccine in April 2015. The results are presented in Table 8.

Table 8. Vaccinated buffaloes and cows found positive with $3 A B C$ antigen of FMD virus existing in natural environment in Bac Son district.

\begin{tabular}{lllll}
\hline NO. & Sample taking time (month/year) & No. of samples examined & No. of samples positive & Rate (\%) \\
\hline 1 & $5 / 2015$ (1 month after vaccination) & 10 & 70 \\
2 & $6 / 2015$ (2 months after vaccination) & 10 & 6 \\
3 & $8 / 2015$ (3 months after vaccination) & 10 & 60 \\
\hline
\end{tabular}


Of the 30 blood samples of the buffaloes and cows taken one, two, and three months after vaccination, $60 \%$ to $70 \%$ were found positive with $3 \mathrm{ABC}$ antigen of the FMD virus existing in the environment.

The results correspond with the local reality. In Bac Son district, FMD occurred in many consecutive years. Some buffaloes and cows were treated and showed no symptom of the disease, yet still carried the viruses and release them to the environment, which infected the cattles, both vaccinated and non-vaccinated ones, and cause the outbreaks of the disease every year. Similar to the results discussed in tai Table 6 , the buffaloes and cows here were also the source of the disease in the environment. If other buffaloes, cows or other sensitive cattles such as pigs and goats are not vaccinated, they could easily develop the disease. This result corresponds to that of $[7,9]$.

\subsection{Types of FMD Viruses on the Buffaloes and Cows in Lang Son Province}

\subsubsection{Types of FMD Viruses in the Blood Samples Taken from the Buffaloes and Cows}

Blood samples collected from the vaccinated and nonvaccinated buffaloes and cows in four districts which represented the different areas in Lang Son province. The results are presented in Table 9, and 10.

Table 9. Types of FMD viruses in the blood samples taken from the buffaloes and cows.

\begin{tabular}{|c|c|c|c|c|c|c|c|}
\hline \multirow{2}{*}{ Areas (districts) } & \multirow{2}{*}{$\begin{array}{l}\text { No. of samples } \\
\text { collected }\end{array}$} & \multicolumn{6}{|l|}{ Result } \\
\hline & & Type O & Rate (\%) & Type A & Rate (\%) & Type Asia 1 & Rate (\%) \\
\hline Chi Lang & 2 & 0 & 0 & 1 & 50 & 0 & 0 \\
\hline Binh Gia & 7 & 0 & 0 & 1 & 14.28 & 0 & 0 \\
\hline Van Quan & 3 & 2 & 66.6 & 0 & 0 & 0 & 0 \\
\hline Bac Son & 2 & 1 & 50 & 0 & 0 & 0 & 0 \\
\hline Dinh Lap & 3 & 2 & 66.6 & 0 & 0 & 0 & 0 \\
\hline Loc Binh & 2 & 0 & 0 & 1 & 50 & 0 & 0 \\
\hline Van Lang & 2 & 1 & 50 & 0 & 0 & 0 & 0 \\
\hline Total & 21 & 6 & 28.5 & 3 & 14.2 & 0 & 0 \\
\hline
\end{tabular}

Table 9 shows that out of the 21 blood samples from the buffaloes and cows with FMD collected in the districts of Chi Lang, Binh Gia, Bac Son, Dinh Lap, Loc Binh, Van Lang and Van Quan, 6 belongs to type O virus (Van Quan, Dinh Lap, Van Lang and Bac Son); 3 belong to FMD virus type A (Chi Lang, Loc Binh and Binh Gia); virus type Asia 1 was not found. Thus, the viruses found in the seven districts belong to two types: type $\mathrm{O}$ (accounting for $28.5 \%$ ) and type A (accounting for $14.2 \%$ ). The result correspond to the reports of the Department of Animal Health on the occurrence and types of FMD viruses on the buffaloes and cows in Vietnam in the two years of 2014, 2015, and OIE's update on the types of FMD viruses on buffaloes and cows in the world (2016).

\subsubsection{Types of FMD Viruses from the Clinical Samples of Epithelium Tissue of Infected Buffaloes and Cows}

In order to identify the types of FMD viruses in the area, 35 clinical samples of epithelium tissue, mouth, toungue, and the hoof gaps of buffaloes and cows with FMD in six district in Lang Son was collected in 2014 and 2015, using RT-PCR. The results are presented in Table 10 .

Table 10. Types of FMD viruses from the clinical samples of epithelium tissue of infected buffaloes and cows.

\begin{tabular}{|c|c|c|c|c|c|c|c|}
\hline \multirow{2}{*}{ No. } & \multirow{2}{*}{ Areas (districts) } & \multicolumn{6}{|l|}{ Result } \\
\hline & & No. of Samples collected & No. of positive samples & Rate (\%) & Type 0 & Type A & Type Asia1 \\
\hline 1 & Dinh Lap & 2 & 2 & 100 & 1 & 1 & 0 \\
\hline 2 & Van Lang & 1 & 1 & 100 & 0 & 1 & 0 \\
\hline 3 & Chi Lang & 2 & 2 & 100 & 1 & 1 & 0 \\
\hline 4 & Loc Binh & 1 & 1 & 100 & 1 & 0 & 0 \\
\hline 5 & Bac Son & 1 & 1 & 100 & 1 & 0 & 0 \\
\hline 6 & Van Quan & 1 & 1 & 100 & 0 & 1 & 0 \\
\hline
\end{tabular}

The results show that all the eight epithelium tissue samples collected from the infected buffaloes and cows in the six districts with FMD outbreaks in the two years of 2014 and 2015 were found positive. In other words, the positive rate was $100 \%$. Of which, half were positive with FMD virus type $\mathrm{O}$, and the other half were positive with type A. None was found positive with type Asial virus. The result corresponds to that of Table 8 which identifies the types of FMD virus. This result was similar to that of $[2,3,4,12,17$, and 18].

\subsection{Vaccines for the Buffaloes and Cows in Lang Son Province}

\subsubsection{Types of FMD Vaccines for the Buffaloes and Cows}

Based on the types of FMD virus found above, and the capacity of vaccine provision in Vietnam, recommendation on the suitable types of FMD vaccines was made to the Animal Health Sub-Department of the province so as they could vaccinate their cattles accordingly. The results are presented in table 11 . 
Table 11. Vaccination of the buffaloes and cows in Lang Son.

\begin{tabular}{lllll}
\hline \multirow{2}{*}{ Districts } & \multicolumn{2}{l}{ Types of virus found } & \multirow{2}{*}{ Type of vaccines recommended } \\
\cline { 2 - 5 } & Type $\mathbf{O}$ & Type A & Type Asia 1 & Bivalent vaccine types O, A \\
\hline Van Lang & 1 & 1 & 0 & Bivalent vaccine types O, A \\
Chi Lang & 6 & 3 & 0 & Bivalent vaccine types O, A \\
Bac Son & 1 & 1 & 0 & Bivalent vaccine types O, A \\
Binh Gia & 1 & 1 & 0 & Bivalent vaccine types O, A \\
Van Quan & 8 & 2 & 0 & \\
\hline
\end{tabular}

Table 11 shows that the local Animal Health SubDepartment selected Aftovax Bivalent vaccine types $\mathrm{O}$ and $\mathrm{A}$ for the buffaloes and cows in five districts of Van Lang, Chi Lang, Bac Son, Binh Gia and Van Quan. The Bivalent vaccine types $\mathrm{O}$ và $\mathrm{A}$ meet the required scientific criteria, suitable to the condition of the local areas and the instruction of the Department of Animal Health of Vietnam. This finding was similar to that of $[17,18]$.

\subsubsection{FMD Vaccination for the Buffaloes and Cows}

A retrospective study on FMD vaccination for the buffaloes and cows in Lang Son province in the years 2011, 2012, 2013, 2014 and 2015. The results are presented in table 12 .

Table 12. FMD vaccination for the buffaloes and cows in Lang Son province from 2011 to 2015.

\begin{tabular}{llll}
\hline Year & $\begin{array}{l}\text { No. planned for } \\
\text { vacination }\end{array}$ & $\begin{array}{l}\text { No. } \\
\text { vaccinated }\end{array}$ & $\begin{array}{l}\text { Rate of implementation } \\
\text { vs planning (\%) }\end{array}$ \\
\hline 2011 & 202,700 & 78,018 & 38.49 \\
2012 & 204,000 & 164,079 & 80.43 \\
2013 & 165,458 & 162,789 & 98.34 \\
2014 & 164,200 & 134,685 & 82.02 \\
2015 & 165,800 & 161,657 & 97.50 \\
\hline
\end{tabular}

Table 12 shows that the vaccination of the buffaloes and cows in Lang Son met the technological requirements on the proportion of the herds being vaccinated i.e. from $80.43 \%$ to $97.50 \%$, except for the year 2011 when the rate of vaccinated cattle was low $(38.49 \%)$.

\subsection{Immune Response and Duration of the Buffaloes and Cows in Lang Son Province}

In order to assess the level of immune response and duration of the buffaloes and cows after vaccination (Aftovax Bivalent, 2 types $\mathrm{O}$ and A produced by Merial - France), blood samples of the buffaloes and cows were collected at days 30, 60, 120 and 180 after being vaccinated in three areas previously experienced FMD outbreaks with the following variations: (i) one shot for the cattle living in the areas previously affected by FMD outbreaks and for those which had been vaccinated six months before; and (ii) two shots for the ones which had never been vaccinated before. The samples were then examined in the laboratory for antibody titer assessment using ELISA method. The results are shown in Table 13.

Table 13. Protection for the buffaloes and cows injected with FMD vaccines.

\begin{tabular}{|c|c|c|c|c|c|c|c|}
\hline Areas & $\begin{array}{l}\text { Samples taken at No. of } \\
\text { days after vaccination }\end{array}$ & $\begin{array}{l}\text { No. of samples } \\
\text { examined }\end{array}$ & $\begin{array}{l}\text { Sample } \\
\text { collection date }\end{array}$ & $\begin{array}{l}\text { No. of } \\
\text { samples (+) }\end{array}$ & $\begin{array}{l}\text { Possitive } \\
\text { rate }(\%)\end{array}$ & $\begin{array}{l}\text { No. of samples } \\
\text { protected }\end{array}$ & $\begin{array}{l}\text { Rate of } \\
\text { protection }(\%)\end{array}$ \\
\hline Bac Son & 30 & 29 & 29 May 2015 & 29 & 100 & 28 & 96.5 \\
\hline Van Lang & 30 & 30 & 01 Jun 2015 & 30 & 100 & 30 & 100 \\
\hline Lang Son City & 30 & 30 & 02 Jun 2015 & 30 & 100 & 26 & 86.6 \\
\hline Bac Son & 60 & 29 & 30 Jun 2015 & 29 & 100 & 25 & 86.2 \\
\hline Van Lang & 60 & 30 & 02 Jul 2015 & 30 & 100 & 26 & 86.6 \\
\hline Lang Son City & 60 & 30 & 03 Jul 2015 & 30 & 100 & 25 & 83.3 \\
\hline Van Lang & 120 & 30 & 05 Sept 2015 & 30 & 100 & 22 & 73.3 \\
\hline Lang Son City & 120 & 30 & 06 Sept 2015 & 30 & 100 & 21 & 70.0 \\
\hline Bac Son & 180 & 29 & 30 Nov 2015 & 18 & 62.0 & 8 & 44.4 \\
\hline Van Lang & 180 & 30 & 02 Dec 2015 & 21 & 70.0 & 9 & 42.8 \\
\hline Lang Son City & 180 & 30 & 03 Dec 2015 & 20 & 66.6 & 6 & 30.0 \\
\hline
\end{tabular}

According to the regulations of the Department of Animal Health of Vietnam, it is required that vaccination of FMD vaccines be done in accordance with the instruction document No. 752/TY-DT issued by the Department on 16 June 2006, and the instruction of the vaccine providers. Thus, for the buffaloes and cows which had never been vaccinated before, it was required that after 28 days after the first shot, the second shot be done with the same type of vaccine. After that, it is necessary to repeat the shots every six months to ensure immunity. The number of buffaloes and cows vaccinated had to be at least $80 \%$ of the total herd.
Table 13 shows that $100 \%$ of the vaccinated buffaloes and cows had immunity response. The rate of protection was from $86.6 \%$ to $100 \% 30$ days after vaccination, from $83.3 \%$ to $86.6 \% 60$ days after vaccination; 120 days after vaccination, the rate of protection seemed to be decrease, with protection rate accounted for $70 \%$ to $75.8 \%$; 180 days after vaccination, the rate of positive samples (with antibody titer against the types $\mathrm{O}, \mathrm{A}$ of FMD viruses) only $62 \%$ to $70 \%$ of the herd are protected. The rate of protection decreased dramatically, with only $30 \%$ to $44.4 \%$. The results were similar to the technical criteria issued by the 
Department of Animal Health of Vietnam. In order to ensure protection for the cattle, six months after the first shot, the cattle had to be injected with the second shot of FMD vaccines. This result was similar to that of $[8,16]$.

\section{Conclusion}

FMD on the buffaloes and cows in Lang Son occurred repeatedly in 11 districts and towns in Lang Son province from 2011 to 2015 . With the total of 187 outbreaks, on average, there were 3.4 outbreaks per year in each district or town.

FMD in Lang Son occurred irregularly. In some districts, there might be FMD outbreaks in two or three consecutive years (E.g. Binh Gia, Van Quan) while in some others, it occurred only once (e.g. Cao Loc district and Lang Son city).

In total, the buffaloes and cows with FMD accounted for $1.26 \% /$ year, with buffaloes accounted for $1.39 \% /$ year, and cows $0.75 \%$ /year. FMD on the buffaloes and cows in Lang Son was under the influence of (i) the weather and climate conditions (especially the years with extremely cold winter), (ii) the seasonal agricultural practice in the locality (during the time of the year when the cattle were used for ploughing and pulling carts for the crops, their health was relatively declined), and (iii) the results of vaccination in early Autumn - Winter season (the smaller the number of cattle vaccinated, the higher the number of cattle infected). These influences were clearly observed in 2011 with the highest number of cattle infected (8,929 infected cattle, accounting for 5.3\% of the herds, whereas the average rate of infection in the whole five studied years was $1.26 \%$ ).

In Lang Son, the sources of FMD were identified as mainly came from the infected cattle which had been medically treated and clear of the symptoms, yet still carried and shed the virus to the environment.

On average, the rate of natural virus infection on the cattle in Lang Son was $33.23 \%$. Of which, the rate was highest in the following districts: Bac Son (66.66\%), Van Quan (50\%), Trang Dinh (32.88\%) and Binh Gia (28.57\%).

The virus causing FMD on the cattle in Lang Son belong to type $\mathrm{O}$ and type A. While type Asia 1 virus had occurred in some other provinces in Vietnam, it was not found in Lang Son. Thus, the suitable vaccine for the cattle in Lang Son would be Aftovax Bivalent, with 2 types of $\mathrm{O}$ and $\mathrm{A}$.

After being injected with FMD vaccine, $100 \%$ of the cattle had immune response. 30 days after vaccination, the rate of protection varied from $86.6 \%$ to $100 \%$. Six months after the first vaccination shot, a second one must be done for the vaccination to be effective.

\section{Acknowledgments}

We would like to send out special thanks to OIE and OIE Bangkok for their financial and technical supports, and the help of the Department of Animal Health of Vietnam, SubDepartment of Animal Health in Lang Sơn, and colleagues who helped to make this study possible.

\section{References}

[1] Anh B. Q, Nam H. V (2001). Foot and Mouth Disease in Southeast Asia. Journal of Veterinaty Science and Technology $8,90-93$.

[2] Alexandersen, S., Z. Zhang, A. I. Donaldson, and A. J. Garland (2003). The pathogenesis and diagnosis of foot-andmouth disease. J. Comp. Pathol. 129: 1-36.

[3] Araujo, J. P., Jr., H. J. Montassier, and A. A. Pinto (2002). Extensive antigenic and genetic variation among foot-andmouth disease type A viruses isolated from the 1994 and 1995 foci in Sao Paulo, Brazil. Vet. Microbiol. 84: 15-27.

[4] Barend M. de C. Bronsvoort, Ian G. Handel, Charles K. Nfon, Karl-Johan Sørensen, Viviana Malirat, Ingrid Bergmann, Vincent N. Tanya, and Kenton L. Morgan (2016). Redefining the "carrier" state for foot-and-mouth disease from the dynamics of virus persistence in endemically affected cattle populations. Sci Rep. 2016; 6: 29059.

[5] Benvenisti, L., A. Rogel, L. Kuznetzova, S. Bujanover, Y. Becker, and Y. Stram (2001). Gene gun-mediated DNA vaccination against foot-and-mouth disease virus. Vaccine 19: 3885-3895.

[6] Bergmann, I. E., P. A. de Mello, E. Neitzert, E. Beck, and I. Gomes (1993). Diagnosis of persistent aphthovirus infection and its differentiation from vaccination response in cattle by use of enzyme-linked immunoelectrotransfer blot analysis with bioengineered nonstructural viral antigens. Am. J. Vet. Res. 54: 825-831.

[7] Bergmann, I. E., V. Malirat, E. Neitzert, E. Beck, N. Panizzuti, C. Sanchez, and A. Falczuk (2000). Improvement of a serodiagnostic strategy for foot-and-mouth disease virus surveillance in cattle under systematic vaccination: a combined system of an indirect ELISA $3 \mathrm{ABC}$ with an enzyme-linked immunoelectrotransfer blot assay. Arch. Virol. 145: 473-489.

[8] Berinstein, A., C. Tami, O. Taboga, E. Smitsaart, and E. Carrillo (2000). Protective immunity against foot-and-mouth disease virus induced by a recombinant vaccinia virus. Vaccine 18: 2231-2238.

[9] Chuc H. D, Long N. T (2003). Detection of buffaloes and cows with FMD using ELISA CHEKIT - FMD - 3ABC kits. Journal of Veterinaty Science and Technology 10, 14-16.

[10] Condy, J. B., R. S. Hedger, C. Hamblin, and I. T. Barnett (1985). The duration of the foot-and-mouth disease virus carrier state in African buffalo (i) in the individual animal and (ii) in a free-living herd. Comp. Immunol. Microbiol. Infect. Dis. 8: 259-265.

[11] Dzung N. T (2000). Foot and Mouth Disease. Journal of Veterinaty Science and Technology 7, 8-16.

[12] Hemadri, D., C. Tosh, R. Venkataramanan, A. Sanyal, A. R. Samuel, N. J. Knowles, and R. P. Kitching (2000). Genetic analysis of foot-and-mouth disease virus type $\mathrm{O}$ isolates responsible for field outbreaks in India between 1993 and 1999. Epidemiol. Infect. 125: 729-736.

[13] Knowles, N. J., and A. R. Samuel (2003). Molecular epidemiology of foot-and-mouth disease virus. Virus Res. 91: 65-80. 
[14] Knowles, N. J., A. R. Samuel, P. R. Davies, R. P. Kitching, and A. I. Donaldson (2001). Outbreak of foot-and-mouth disease virus serotype $\mathrm{O}$ in the UK caused by a pandemic strain. Vet. Rec. 148: 258-259.

[15] Marquardt, O., O. C. Straub, R. Ahl, and B. Haas (1995). Detection of foot-and-mouth disease virus in nasal swabs of asymptomatic cattle by RT-PCR within 24 hours. J. Virol. Methods 53: 255-261.

[16] Mayr, G. A., V. O'Donnell, J. Chinsangaram, P. W. Mason, and M. J. Grubman (2001). Immune responses and protection against foot-and-mouth disease virus (FMDV) challenge in swine vaccinated with adenovirus-FMDV constructs. Vaccine 19: $2152-2162$.

[17] OIE (2016). Manual of Diagnostic Tests and Vaccines for Terrestrial Animals 2016. Foot and mouth disease (Version adopted in May 2012).

[18] Report on animal health in Vietnam 2014, 2015. DAH.
[19] Reid, S. M., Ferris, N. P., Hutchings, G. H., Samuel, A. R., Knowles, N. J (2000a). Primary diagnosis of foot-and-mouth disease by reverse transcription polymerase chain reaction. J. Virol. Methods 89, 167-176.

[20] Sabenzia Nabalayo Wekesa, Abraham Kiprotich Sangula, Graham J Belsham, Kirsten Tjornehoj Vincent B Muwanika, Francis Gakuya, Dominic Mijele and Hans Redlef Siegismund (2015). Characterisation of recent foot-and-mouth disease viruses from African buffalo (Syncerus caffer) and cattle in Kenya is consistent with independent virus populations. BMC Veterinary Research 2015 11: 17.

[21] Scott M. Reid, Katja Ebert, Katarzyna Bachanek-Bankowska, Carrie Batten, Anna Sanders, Caroline Wright, Andrew E. Shaw, Eoin D. Ryan, Geoffrey H. Hutchings, Nigel P. Ferris, David J. Paton, Donald P. King (2009). Performance of realtime reverse transcription polymerase chain reaction for the detection of Foot-and-mouth disease virus during field outbreaks in the United Kingdom in 2007. J Vet Diagn Invest 21: 321-330 (2009) 